\title{
DIRECT MEASUREMENT OF MERCURY REACTIONS IN COAL POWER PLANT PLUMES
}

Technical Progress Report

for the period March 18, 2004 through September 17, 2004.

Prepared for:

AAD Document Control

U.S. Department of Energy

National Energy Technology Laboratory

PO Box 10940, MS 921-107

Pittsburgh, PA 15236-0940

DOE Award DE-FC26-03NT41724

Performance Monitor: William Aljoe

Prepared by

Leonard Levin

Electric Power Research Institute

3420 Hillview Ave. Palo Alto, California 94304

June 2006 


\section{DISCLAIMER}

This report was prepared as an account of work sponsored by an agency of the United States Government. Neither the United States Government nor any agency thereof, nor any of their employees, makes any warranty, express or implied, or assumes any legal liability or responsibility for the accuracy, completeness, or usefulness of any information, apparatus, product, or process disclosed, or represents that its use would not infringe privately owned rights. Reference herein to any specific commercial product, process, or service by trade name, trademark, manufacturer, or otherwise does not necessarily constitute or imply its endorsement, recommendation, or favoring by the United States Government or any agency thereof. The views and opinions of authors expressed herein do not necessarily state or reflect those of the United States Government or any agency thereof.

\section{ACKNOWLEDGMENT}

This report was prepared with the support of the U.S. Department of Energy (DOE) National Energy Technology Laboratory Award No. DE-FC26-03NT41724. Any opinions, findings, conclusions, or recommendations expressed herein are those of the author(s) and do not necessarily reflect the views of DOE. 


\title{
DIRECT MEASUREMENT OF MERCURY REACTIONS IN COAL POWER PLANT PLUMES
}

\begin{abstract}
This project was awarded under U.S. Department of Energy (DOE) National Energy Technology Laboratory (NETL) Program Solicitation DE-PS26-02NT41422 and specifically addresses Program Area of Interest: \#5 - Environmental and Water Resources. The project team includes the Electric Power Research Institute (EPRI) as the contractor and the University of North Dakota Energy \& Environmental Research Center (EERC) and Frontier Geosciences as subcontractors. Wisconsin Energies and its Pleasant Prairie Power Plant acted as host for the field-testing portion of the research.

The project is aimed at clarifying the role, rates, and end results of chemical transformations that may occur to mercury that has been emitted from elevated stacks of coal-fired electric power plants. Mercury emitted from power plants emerges in either its elemental, divalent, or particulate-bound form. Deposition of the divalent form is more likely to occur closer to the source than that of the other two forms, due to its solubility in water. Thus, if chemical transformations occur in the stack emissions plume, measurements in the stack may mischaracterize the fate of the material. Initial field and pilot plant measurements have shown significant and rapid chemical reduction of divalent to elemental mercury may occur in these plumes.
\end{abstract}

Mercury models currently assume that the chemical form of mercury occurring in stacks is the same as that which enters the free atmosphere, with no alteration occurring in the emissions plume. Recent data indicate otherwise, but need to be evaluated at full operating scale under field conditions.

Prestbo and others have demonstrated the likelihood of significant mercury chemical reactions occurring in power plant plumes (Prestbo et al., 1999; MDNR-PPRP, 2000; EERC, 2001). This experiment will thus increase our understanding of mercury atmospheric chemistry, allowing informed decisions regarding source attribution.

The experiment was carried out during the period August 22-September 5, 2003. The experimental site was the Pleasant Prairie Power Plant in Pleasant Prairie, Wisconsin, just west of Kenosha. The experiment involved using an aircraft to capture emissions and document chemistry changes in the plume. While using the airplane for sampling, supplemental fastresponse sensors for NOx, connected to data loggers, were used to gauge entry and exit times and transect intervals through plume emissions material. The Frontier Geosciences Static Plume Dilution Chamber (SPDC) was employed simultaneously adjacent to the stack to correlate its findings with the aircraft sampling, as well as providing evaluation of the SPDC as a rapid, less costly sampler for mercury chemistry. A complementary stack plume method, the Dynamic Plume Dilution (DPD) was used in the latter portion of the experiment to measure mercury speciation to observe any mercury reduction reaction with respect to both the reaction time ( 5 to 30 seconds) and dilution ratio. In addition, stack sampling using the 
"Ontario Hydro" wet chemistry method and continuous mercury monitors (CMM) were used to establish the baseline chemistry in the stack. Comparisons among stack, SPDC, DPD and aircraft measurements allow establishment of whether significant chemical changes to mercury occur in the plume, and of the verisimilitude of the SPDC and DPD methods.

This progress report summarizes activities during a period of results review from the stack/aircraft subcontractor, data analysis and synthesis, and preparation and presentation of preliminary results to technical and oversight meetings. 
TABLE OF CONTENTS

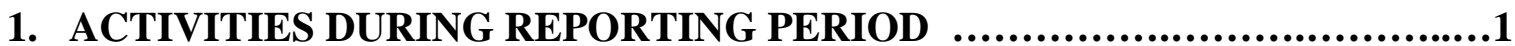

2. APPENDIX A........................................................................ 


\section{DIRECT MEASUREMENT OF MERCURY REACTIONS IN COAL POWER PLANT PLUMES \\ 1) ACTIVITIES DURING THE REPORTING PERIOD}

Papers and Presentations

Subcontractor University of North Dakota Energy and Environmental Research Center (UNDEERC) served as primary author and presenter on a summary paper describing the Pleasant Prairie measurements at the 2004 EPRI/U.S. DOE/U.S. EPA Megasymposium, Washington, D.C. (see Appendix A).

A presentation on the work was made by Subcontractor UNDEERC at the $7^{\text {th }}$ International Conference on Mercury as a Global Pollutant, Ljubljana, Slovenia, June-July 2004.

Principal Investigator Leonard Levin presented summary results and interpretation of results for source-receptor relationships to conferences, including:

- University of Heidelberg Institute for Environmental Geochemistry, August 2004

- EPRI Environment Division Advisors, Boston, September 2004

- United Nations Global Environmental Inventory Activity workshop, Paris, France, June 2004

- United Nations Environment Program Regional Mercury workshop, Bangkok, Thailand, April 2004

\section{Subcontractor Reporting}

Laboratory analyses and data processing proceeded at the laboratories of Subcontractor UNDEERC

Repeated phone and e-mail communications with Subcontractor Frontier Geosciences (FG) were engaged in by Principal Investigator EPRI. Subcontractor FG indicated data processing was underway while simultaneously preparing summary papers for presentations at the $7^{\text {th }}$ International Conference on Mercury as a Global Pollutant and elsewhere. 


\title{
2) APPENDIX A
}

\section{PROJECT PRESENTATION AT 2004 MEGASYMPOSIUM}

\section{Evaluation of Mercury Speciation in a Power Plant Plume}

Paper \#167

\author{
Dennis L. Laudal \\ Grant E. Dunham \\ Energy \& Environmental Research Center \\ Box 9018 \\ Grand Forks, ND 58202-9018
}

\section{Leonard Levin}

EPRI

3412 Hillview Avenue

PO Box 10412

Palo Alto, CA 94303

\section{ABSTRACT}

There is no known benign tracer material that mimics the complex behavior of mercury $(\mathrm{Hg})$ in the natural environment. For that reason, a combination of source and receptor measurements and computer modeling are required for tracking $\mathrm{Hg}$ cycling. Although in-stack $\mathrm{Hg}$ speciation measurements are essential for the development of control technologies and to provide source data for atmospheric deposition models, $\mathrm{Hg}$ transformations that may occur in the emissions plume will also determine the rate and the form of $\mathrm{Hg}$ deposited in waterways. Yet such processes are poorly understood and not currently incorporated in atmospheric models of Hg. Therefore, EPRI and the U.S Department of Energy have funded surface and aircraft studies of stack emissions and plume chemistry at two power plants. The first study was at Plant Bowen, Cartersville, Georgia, operated by Georgia Power, part of the Southern Company. Aircraft studies were conducted by the Tennessee Valley Authority, with surface measurements by the Energy \& Environmental Research Center (EERC) and by Frontier Geosciences. The second study was at the Pleasant Prairie Power Plant, Pleasant Prairie, Wisconsin, operated by We Energies; there, surface and air measurements were carried out by the EERC, with additional studies at the stack by Frontier. The primary focus of this paper is on work conducted by the EERC at Pleasant Prairie.

The overall project goal was to gain an understanding of $\mathrm{Hg}$ chemistry as a plume is transported downwind from the stack. This was to be carried out by flying an airplane through the plume at several locations (a point nearest the stack, 5 miles from the stack, and 10 miles from the stack) and measuring the speciated $\mathrm{Hg}$ composition in the plume at each location. The speciated $\mathrm{Hg}$ results obtained at the stack were then compared to the measurements obtained 
from the plume sampling, using dilution factors to accommodate turbulent dispersion and allow comparison on a common basis.

In general, using a dilution factor based on the plume and stack $\mathrm{NO}_{\mathrm{x}}$, a reasonable $\mathrm{Hg}$ mass balance was obtained when comparing the $\mathrm{Hg}$ in the stack to the $\mathrm{Hg}$ in the plume. This indicates there was little if any loss of $\mathrm{Hg}$ from the plume material between the stack and the 10-mile sample point. However, there appeared to be a lower fraction of reactive gaseous mercury (RGM) in the plume compared to the RGM value in the stack, with a corresponding increase in the proportion of elemental mercury $\left(\mathrm{Hg}^{0}\right)$. The percentage of $\mathrm{Hg}^{0}$ in the stack was $66 \%$ compared to values of $84,89 \%$, and $88 \% \mathrm{Hg}^{0}$ in the plume measured closest to the stack, at 5 miles from the stack, and at 10 miles from the stack, respectively.

\section{INTRODUCTION}

Characterization of environmental mercury $(\mathrm{Hg})$ and its atmospheric processes, from emissions to deposition, requires both measurements and model simulations for a full understanding. Although in-stack $\mathrm{Hg}$ speciation measurements are essential to the development of control technologies and to provide data for input into the atmospheric deposition models, the determination of speciation and changes in speciation in emission plumes themselves are required for a complete description of atmospheric $\mathrm{Hg}$. In particular, the rapid temperature changes, mixing with ambient air, and presence of other emitted constituents may impact $\mathrm{Hg}$ chemistry over short time and spatial scales. While substantial research has been done in the past on $\mathrm{Hg}$ transformations with energy production facilitiesdetermining the concentrations of speciated $\mathrm{Hg}$ within combustion and exhaust gas systemslittle has been done to determine the $\mathrm{Hg}$ chemistry, kinetics, and thermodynamics in the stack emissions plume. ${ }^{1}$ It is the $\mathrm{Hg}$ transformations that occur in the plume that determine the rate and the form of $\mathrm{Hg}$ entering the ambient atmosphere after complete mixing of the plume and that partially determines the amount of $\mathrm{Hg}$ deposited in lakes and streams downwind. Therefore, a logical step in $\mathrm{Hg}$ research is to apply known methods and data from in-facility measurements, and from measurements in the ambient atmosphere, to the near-source region through which the plume passes.

Therefore, EPRI and the U.S. Department of Energy (DOE) have funded surface and aircraft studies of stack emissions and plume chemistry at two coal-fired power plants. The first study was at Plant Bowen, Cartersville, Georgia (operated by Georgia Power, part of the Southern Company). Aircraft studies were conducted by the Tennessee Valley Authority (TVA), with surface measurements by the Energy \& Environmental Research Center (EERC) and by Frontier Geosciences. The second study was at the Pleasant Prairie Power Plant, Pleasant Prairie, Wisconsin, operated by We Energies; there, surface and air measurements were carried out by the EERC, with additional studies at the stack by Frontier. The primary focus of this paper is on work conducted by the EERC at Pleasant Prairie. However, this work depends on the earlier source studies conducted by $\mathrm{TVA}^{2,3}$ and the static plume dilution chamber work done by Frontier Geosciences. ${ }^{1,4}$ Additionally, ambient surface measurements made by Atmosphere Research \& Analysis ${ }^{5}$ at the Yorkville SEARCH site some $25 \mathrm{~km}$ from Plant Bowen indicating that there is change in $\mathrm{Hg}$ speciation within the plume must be considered as well. 


\section{PROJECT OBJECTIVES}

The overall project goal is to gain an understanding of $\mathrm{Hg}$ chemistry as a plume is transported downwind from the stack. Specific objective are to:

- Develop sampling techniques to measure speciated $\mathrm{Hg}$ in the plume.

- Develop techniques to determine the location of the plume at various points downwind of the stack.

- Determine the speciation of $\mathrm{Hg}$ emissions at the stack and compare these results to $\mathrm{Hg}$ species obtained from the plume sampling.

- Compute a Hg mass balance using dilution factors and other relevant parameters.

\section{PROJECT DESCRIPTION}

\section{Power Plant Description}

The Pleasant Prairie Power Plant, owned and operated by We Energies, is located in the village of Pleasant Prairie just west of Kenosha, Wisconsin. The Pleasant Prairie plant consists of two units (Units 1 and 2) identical in operation with the exception of one (Unit 2) having a selective catalytic reduction (SCR) system at the time of the measurements. Each unit has an electrostatic precipitator (ESP) for particulate control. The two Pleasant Prairie units share a common single stack. Specifications of the Pleasant Prairie facility are as follows:

- Fuel type: Powder River Basin (PRB) subbituminous coal

- Boiler capacity: 617 MW (each unit)

- Boiler type: opposed-fired pulverized coal (both units)

- $\mathrm{NO}_{\mathrm{x}}$ control: SCR on Unit 2; low-NO $\mathrm{N}_{\mathrm{x}}$ burners on both units

- $\mathrm{SO}_{2}$ control: none; combustion of low-sulfur coal (both units)

- Particulate control: ESP (both units)

The coal is fairly typical of PRB in that both the $\mathrm{Hg}$ and chlorine levels in the coal are comparatively low; the $\mathrm{Hg}$ averaged $0.041 \mu \mathrm{g} / \mathrm{g}$ and the chlorine $10 \mathrm{ppm}$.

\section{Aircraft and Equipment Used for the Project}

The aircraft used for the emissions plume sampling was a turboprop DHC-6-300 Twin Otter deHaviland Vistaliner. Aircraft and crew were supplied by Twin Otter International, Las Vegas, Nevada (the same aircraft was used for the earlier Plant Bowen project). The pilots were very experienced in doing research involving ambient air sampling. The aircraft is shown in Figure 1. This type of aircraft had a number of design and performance characteristics that made it an ideal platform for the project. The twin-engine plane had a relatively large capacity and sufficient on-board electrical supply and could be operated efficiently at low altitudes. These capabilities were accompanied by relatively low fuel consumption at all altitudes. Most importantly for the plume study project, it could be flown at relatively slow speeds (80-160 
knots/150-300 km/hr) and in tight formations, to allow consistent plume traverses at fixed heights and downwind distances.

The $\mathrm{Hg}$ analyzer used in the aircraft (shown in Figure 2) was a fully automated Tekran ${ }^{\circledR}$ Model 2537A Mercury Vapor Analyzer coupled with a Tekran ${ }^{\circledR}$ Model 1130 Mercury Speciation Unit and a Tekran ${ }^{\circledR}$ Model 1135 Particulate Module. The analyzer portion of the system is based on 
Figure 1. Photograph of the DHC-6-300 Twin Otter deHaviland Vistaliner

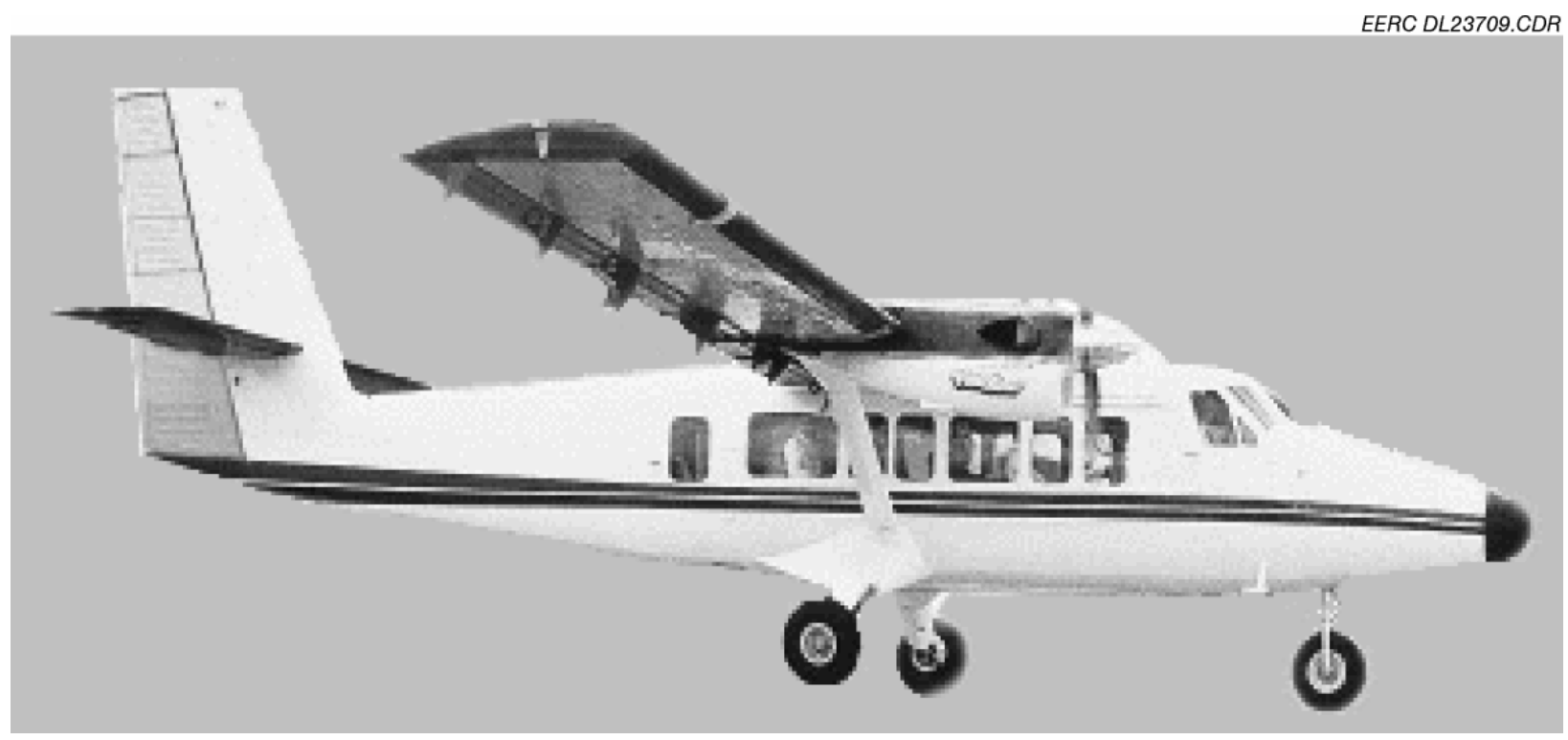

Figure 2. Schematic of the Tekran Mercury System

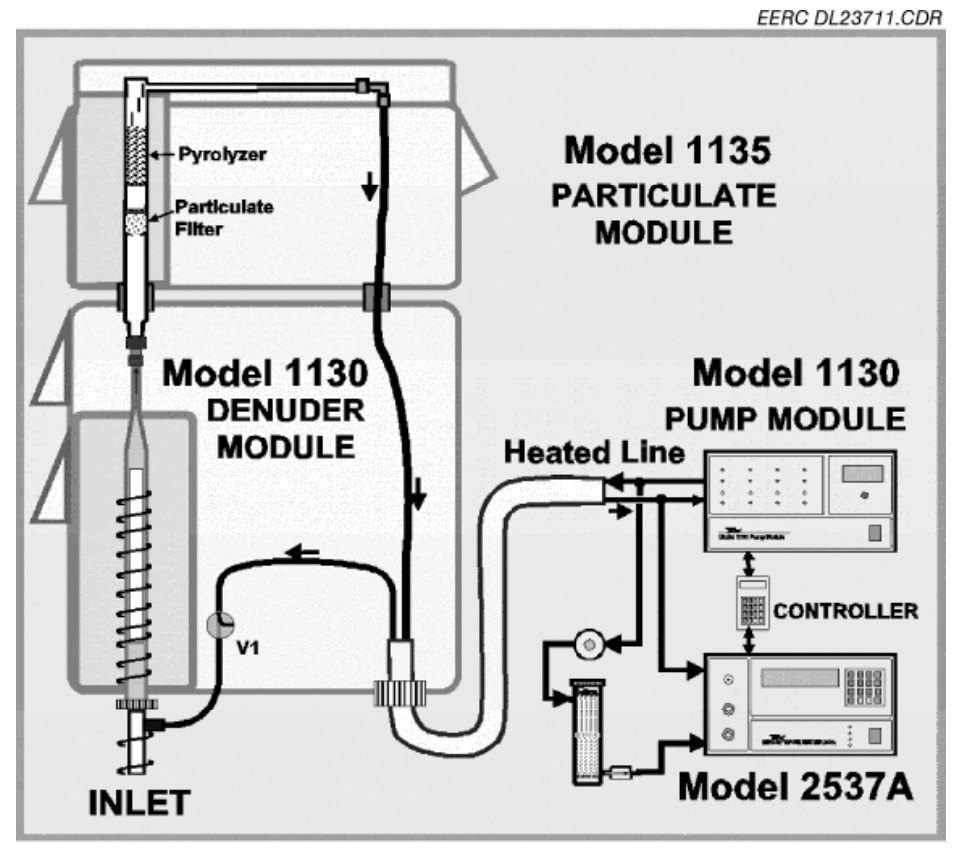

the principle of atomic fluorescence and has detection limits $<1 \mathrm{pg} / \mathrm{m}^{3}$. With this system we were able to simultaneously measure elemental mercury $\left(\mathrm{Hg}^{0}\right)$, reactive gaseous mercury (RGM), and particulate-bound $\mathrm{Hg}$ species during the flight. Therefore, it was possible to rapidly evaluate data each day and make sampling decisions for succeeding flights.

To compare the $\mathrm{Hg}$ concentrations in the plume to those in the stack, a dilution factor was determined. Based on the earlier tests conducted at Plant Bowen by TVA, ${ }^{2}$ it was decided that 
the $\mathrm{NO}_{\mathrm{x}}$ concentration in the stack vs. that in the plume at traverse distances be used to determine the dilution factor as shown in the following equation:

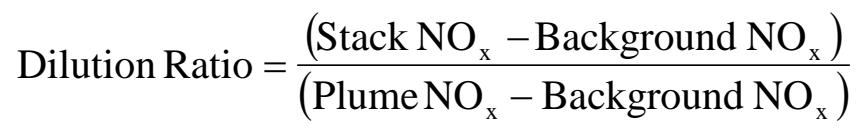

In addition, the $\mathrm{NO}_{\mathrm{x}}$ analyzer was used to determine the location of the plume; the rapid response of the $\mathrm{NO}_{\mathrm{x}}$ analyzer allowed recording of $\mathrm{NO}_{\mathrm{x}}$ concentration changes as the aircraft crossed the edges of plume material. The assumption of neutral buoyancy and equivalent Froude numbers for all plume constituents at and beyond equivalent stack height and distance was used to calculate in-plume portions of the $\mathrm{Hg}$ concentrations. The $\mathrm{NO}_{\mathrm{x}}$ analyzer that was used for this project was a dual range Model 42C Thermo Electron Ambient Air $\mathrm{NO}_{\mathrm{x}}$ Analyzer. This analyzer was able to measure $0-50 \mathrm{ppb} \mathrm{NO}_{\mathrm{x}}$ in its low range and up to $500 \mathrm{ppb}$ $\mathrm{NO}_{\mathrm{x}}$ in its high range.

\section{EXPERIMENTAL APPROACH}

\section{Aircraft Sampling Locations}

Following background sampling at a location upwind of the stack, aircraft sampling was done at three locations downwind of the plume. The first location was approximately $1500 \mathrm{ft}$ from the stack (the closest the plane was permitted to approach the stack). The second and third locations were approximately 5 and 10 miles downwind of the stack, respectively. Figure 3 is an example of the flight diagram showing sampling locations and patterns. As can be seen, a number of different patterns were flown at the closest sampling point in an effort to optimize the time in the plume. At the other two locations a race track pattern was flown. Aircraft position vs. time was determined using a satellite-based global positioning system.

Determining the altitude and direction of the plume was done based on a combination of visual inspection (location closest to the stack, at which plume material was evident visually) and the measurements of $\mathrm{NO}_{\mathrm{x}}$ concentrations. Except for the closest location, the Tekran $\mathrm{Hg}$ analyzer was triggered by a $\mathrm{NO}_{\mathrm{x}}$ set point.

Aircraft sampling flights were conducted in daylight under atmospheric conditions that permitted adequate sampling of the stack plume. The weather conditions during the project were fairly consistent with the historical climate record with many fair weather days. In the original test plan the ideal wind speeds were considered to be approximately $2.5-5 \mathrm{~m} / \mathrm{s}$; however, the average wind speeds were somewhat above this, ranging from 5.3 to $8.3 \mathrm{~m} / \mathrm{s}$. These windspeeds were still low enough that the aircraft was able to find the plume and good sampling was able to be completed. 
Figure 3. Example of a Flight Pattern

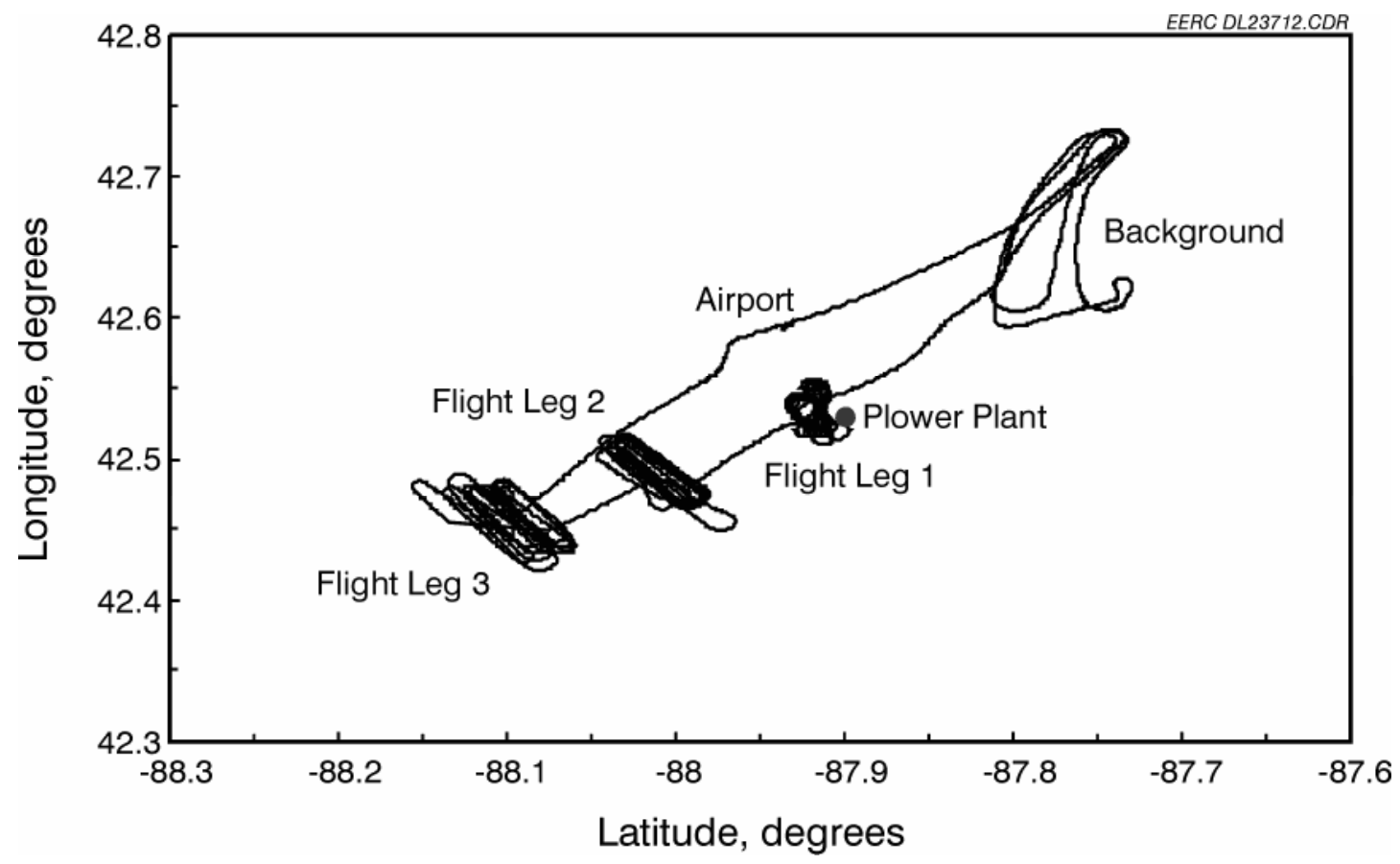

\section{Stack Sampling}

To establish baseline conditions for comparison with the plume samples, in-stack sampling was carried out simultaneously with the flights, providing measurements of the $\mathrm{Hg}$ speciation in the stack. Hg sampling at the stack was completed using the Ontario Hydro $(\mathrm{OH}) \mathrm{Hg}$ speciation sampling method and a continuous mercury monitor (CMM). Prior to the start of the testing, a CMM was placed at the stack outlet and remained there during the entire project. During each flight day, one $\mathrm{OH}$ sample was taken at the stack.

In addition to $\mathrm{Hg}$ measurements by the EERC, the plant operators continuously measured the $\mathrm{NO}_{\mathrm{x}}$ concentration in the stack using a continuous emission monitor. Although the $\mathrm{NO}_{\mathrm{x}}$ concentrations in the stack at the Pleasant Prairie Power Plant were somewhat lower than desired for aircraft plume measurements (since half the flue gas was being treated using SCR), it was still possible to detect a difference between the background and plume, even at 10 miles. The average stack $\mathrm{NO}_{\mathrm{x}}$ concentration was $144 \mathrm{ppm}(\mathrm{v})$.

\section{RESULTS AND DISCUSSION}

\section{Stack Results at Pleasant Prairie}

The $\mathrm{Hg}$ concentrations in the stack are shown in Table 1 and the $\mathrm{OH}$ and CMM sampling in Figure 4. As the results show in Table 1, the $\mathrm{Hg}$ concentrations were relatively constant during the entire duration of the project. The RGM averaged $34.3 \%$ of the total $\mathrm{Hg}$ measured. These results were well-matched by the CMM, as shown in Figure 4. 
Table 1. Stack Ontario Hydro mercury speciation results.*

\begin{tabular}{|l|l|l|l|l|l|}
\hline Date & $\begin{array}{l}\text { Particulate-Bound } \\
\mathbf{H g}, \boldsymbol{\mu g} / \mathbf{N m}^{3}\end{array}$ & $\begin{array}{l}\mathbf{R G M}, \\
\mathbf{\mu g} / \mathbf{N m}^{3}\end{array}$ & $\begin{array}{l}\mathbf{H g}^{\mathbf{0}}, \\
\mathbf{\mu g} / \mathbf{N m}^{3}\end{array}$ & $\begin{array}{l}\mathbf{H g}(\text { Total), } \\
\mathbf{\mu g} / \mathbf{N m}^{3}\end{array}$ & $\begin{array}{l}\mathbf{H g}^{\mathbf{0}} \text { as a \% } \\
\mathbf{o f} \text { Total } \mathbf{H g}\end{array}$ \\
\hline $08 / 27 / 03$ & 0.00 & 3.3 & 6.7 & 10.0 & 67.0 \\
\hline $08 / 29 / 03$ & 0.00 & 3.4 & 6.1 & 9.5 & 64.2 \\
\hline $08 / 30 / 03$ & 0.00 & 3.0 & 6.6 & 9.6 & 68.8 \\
\hline $08 / 31 / 03$ & 0.00 & 4.0 & 5.1 & 9.1 & 56.0 \\
\hline $09 / 02 / 03$ & 0.00 & 2.5 & 5.7 & 8.2 & 69.5 \\
\hline $09 / 04 / 03$ & 0.00 & 3.1 & 6.8 & 9.9 & 68.7 \\
\hline
\end{tabular}

*All concentrations $\left(\mathrm{Nm}^{3}\right)$ are based on 1 atmosphere pressure and $20^{\circ} \mathrm{C}$.

Figure 4. Stack Mercury Emissions at the Pleasant Prairie Power Plant (actual $\mathrm{O}_{2}$ concentrations)

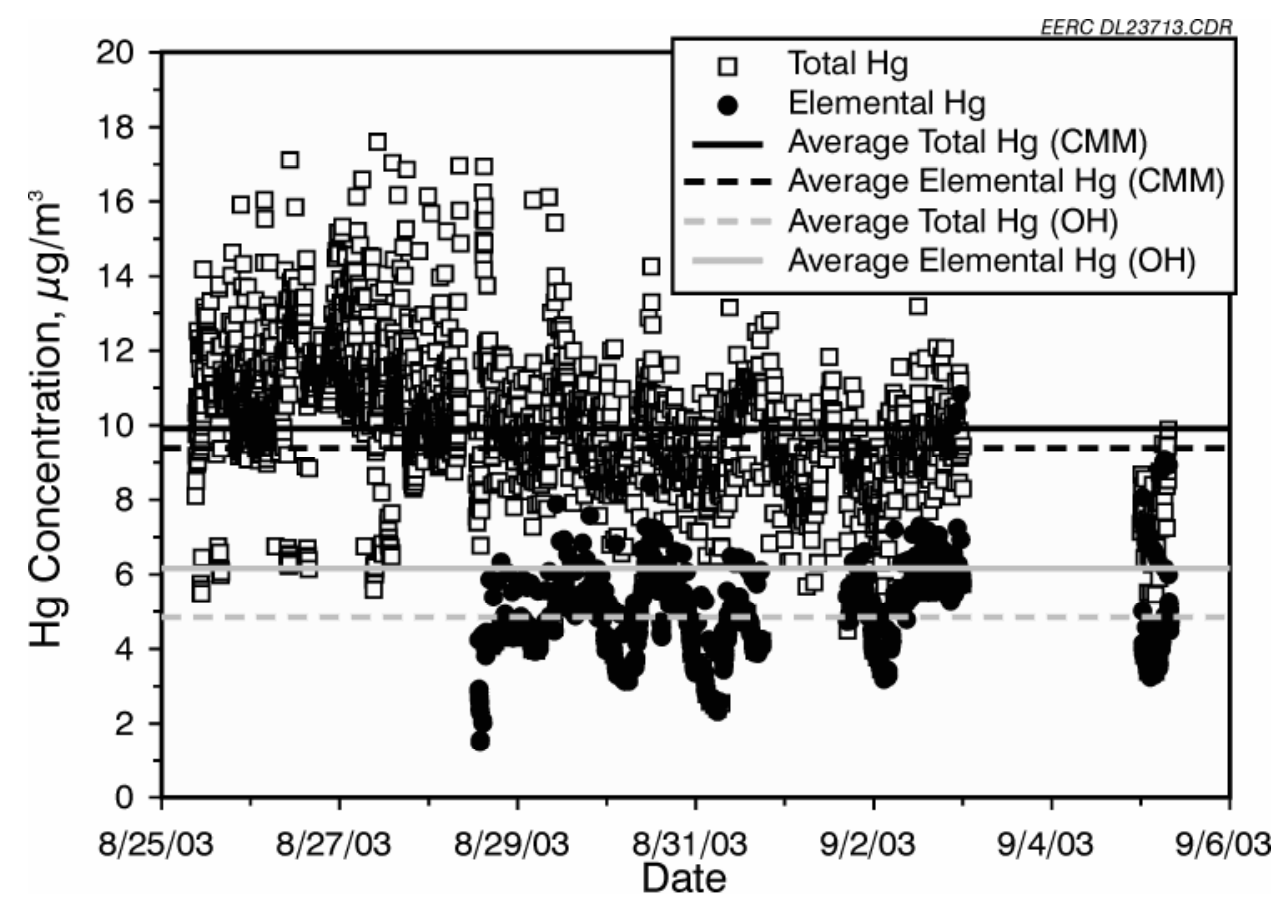

\section{Plume Results at Pleasant Prairie}

A summary of the results from the plume sampling at the Pleasant Prairie plant are presented in Table 2. The plume $\mathrm{Hg}$ concentrations have been converted to equivalent stack concentrations and are presented as such. The plume data were reduced by first correcting for the amount of sampling time in the plume. This gives a $\mathrm{Hg}$ concentration in the plume. The plume concentrations were then converted to an equivalent stack concentration by applying dilution factors which were based on the plume and stack $\mathrm{NO}_{\mathrm{x}}$ concentrations.

A mass balance was calculated using the average total $\mathrm{Hg}$ data from each sampling point each day and the corresponding stack data. The results are presented in Table 3. Although many of the 
Table 2. Average Mercury speciation results for each location.*

\begin{tabular}{|c|c|c|c|c|c|}
\hline \multirow{2}{*}{ Stack } & $\mathrm{Hg}_{\mathrm{p}}$ & $\mathbf{H g}^{0}$, & RG & Tota & $\% \mathrm{Hg}^{0}$ \\
\hline & & & & & \\
\hline Average & 0.00 & 3.2 & 6.2 & 9.4 & 65.7 \\
\hline Std. Dev. & 0.00 & 0.5 & 0.7 & 0.7 & 5.1 \\
\hline 0 Miles & & & & & \\
\hline Average & 0.06 & 10.1 & 2.0 & 12.1 & 83.6 \\
\hline Std. Dev. & 0.04 & 4.9 & 0.5 & 3.4 & 5.3 \\
\hline 5 Miles & & & & & \\
\hline Average & 0.10 & 13.5 & 1.7 & 15.2 & 88.9 \\
\hline Std. Dev. & 0.06 & 10.0 & 0.6 & 5.1 & 3.1 \\
\hline 10 Miles & & & & & \\
\hline Average & 0.09 & 12.8 & 1.6 & 14.4 & 88.2 \\
\hline Std. Dev. & 0.08 & 7.5 & 0.7 & 5.4 & 2.2 \\
\hline
\end{tabular}

$*$ All concentrations are based on normal $(\mathrm{N})$ conditions defined as 1 atmosphere pressure, $20^{\circ} \mathrm{C}$, and $3 \% \mathrm{O}_{2}$.

Table 3. Total Hg mass balance: plume Hg compared to stack Hg.

\begin{tabular}{|c|c|c|c|c|c|c|c|c|}
\hline \multicolumn{3}{|l|}{0 Miles } & \multicolumn{3}{|l|}{5 Miles } & \multicolumn{3}{|l|}{10 Miles } \\
\hline $\begin{array}{l}\text { Total } \mathrm{Hg} \\
\text { in Plume, } \\
\mu \mathrm{g} / \mathrm{Nm}^{3}\end{array}$ & $\begin{array}{l}\text { Total } \mathrm{Hg} \\
\text { in Stack, } \\
\mu \mathrm{g} / \mathrm{Nm}^{3}\end{array}$ & Ratio, \% & $\begin{array}{l}\text { Total } \mathrm{Hg} \\
\text { in Plume, } \\
\mu \mathrm{g} / \mathrm{Nm}^{3}\end{array}$ & $\begin{array}{l}\text { Total } \mathrm{Hg} \\
\text { in Stack, } \\
\mu \mathrm{g} / \mathrm{Nm}^{3}\end{array}$ & Ratio, \% & $\begin{array}{l}\text { Total } \mathrm{Hg} \\
\text { in Plume, } \\
\mu \mathrm{g} / \mathrm{Nm}^{3}\end{array}$ & $\begin{array}{l}\text { Total } \mathrm{Hg} \\
\text { in Stack, } \\
\text { ug } / \mathrm{Nm}^{3}\end{array}$ & Ratio, \% \\
\hline 13.5 & 10.0 & 135 & 15.0 & 10.0 & 150 & 16.5 & 10.0 & 165 \\
\hline 12.1 & 9.7 & 125 & 14.3 & 9.7 & 148 & 17.8 & 9.7 & 184 \\
\hline 10.7 & 9.1 & 118 & 22.0 & 9.1 & 242 & & & \\
\hline 7.8 & 8.2 & 95 & 9.6 & 8.2 & 11 & 7.9 & 82 & 96 \\
\hline 12.0 & 9.9 & 121 & & & & & & \\
\hline 18.2 & 9.9 & 184 & & & & & & \\
\hline
\end{tabular}

mass balance closures are somewhat high, they are quite reasonable considering the variability of the data and the difficult nature of the sampling. The two most likely causes for the high $\mathrm{Hg}$ concentrations are underreported $\mathrm{NO}_{\mathrm{x}}$ concentration, which does not affect the ratio of $\mathrm{Hg}^{0}$ to RGM, or Hg offgassing from the soda lime traps used in the aircraft sampling line when exposed to plume gas. Nonetheless, the ratio of $\mathrm{Hg}^{0}$ to RGM does show an evolution as the plume moves downwind from the stack, implying a change in speciation occurring solely within the plume itself between the stack exit and full dispersion into the ambient atmosphere.

It should be noted there were a number of high readings that corresponded to very high dilution ratios. These results were not included in the average. The high dilution ratios occurred during intermittent aircraft transit of smaller plume eddies separated from the main body of the plume, with relatively high proportions of ambient air sampled in short times, not statistically characteristic of the plume material at that distance from the stack. Even with relatively stable winds, turbulent eddies would result in complex plume structure, causing some passes through the plume to only intersect edges of the material rather than the crosscenterline transects that were sought. These peripheral intersects would capture relatively large proportions of ambient air with markedly lower $\mathrm{NO}_{\mathrm{x}}$ values than the main body of the plume. 
During these sampling episodes, the $\mathrm{NO}_{\mathrm{x}}$ concentration would be just high enough to trigger the zero air inlet valve in the sampling system. Once it was triggered, the valve was set with a delay to stay off for 5 seconds once the $\mathrm{NO}_{\mathrm{x}}$ level again fell below the trigger point. This was done to prevent rapid cycling of the valve. Since the $\mathrm{NO}_{\mathrm{x}}$ concentration was near ambient levels in these segments of the plume, the resulting dilution ratios were artificially high.

The overall results are shown in Figure 5, in a plot of the average percentage of $\mathrm{Hg}^{0}$ in the plume as it moves from the stack exit to 10 miles downwind of the stack. There is a substantial increase in the concentration of $\mathrm{Hg}^{0}$ from the stack to the first sample point, a smaller increase from the first to the second sample point, and then no change from there to the last sample location (10 miles). Overall, the $\mathrm{Hg}^{0}$ increases from $67 \%$ of the total $\mathrm{Hg}$ to $89 \%$ by the time it reaches the 5-mile sample point. The question arises, is this increase real, or does it represent a high bias in the $\mathrm{Hg}^{0}$ concentration measurements in the plume? Several factors could cause the $\mathrm{Hg}^{0}$ concentration (and total $\mathrm{Hg}$ ) to be reported higher in the plume than in the stack. These include the following:

- Low background $\mathrm{Hg}$ readings

- Inefficient trapping of the RGM in the Tekran denuder

- Underreported plume $\mathrm{NO}_{\mathrm{x}}$ concentrations

- Problems with the soda lime traps

Figure 5. Changes in Mercury Speciation as a Function of Distance from the Stack

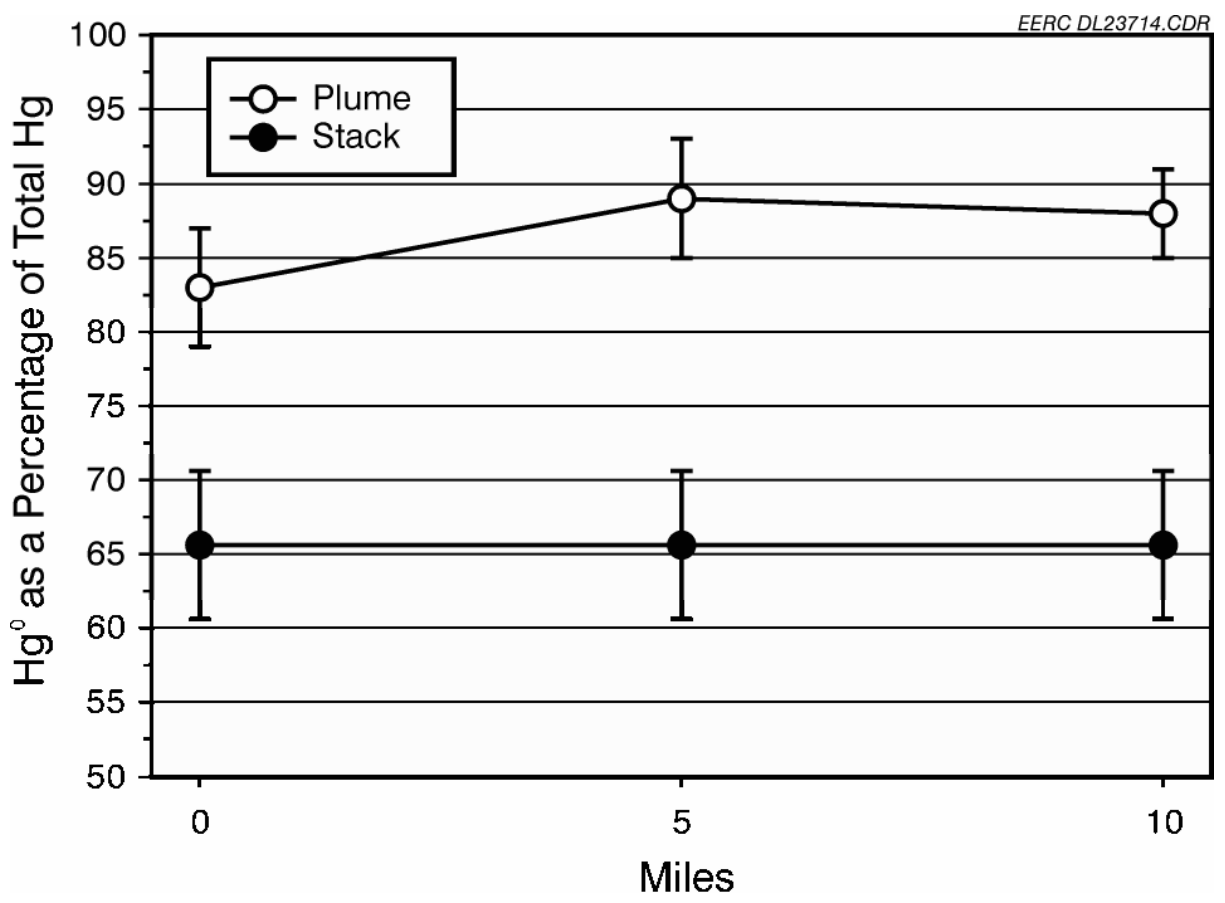




\section{Low Background Mercury Readings}

The subtraction of low background concentrations from the measured plume concentrations would result in higher in-plume concentrations when they are converted to equivalent stack concentrations. However, this does not appear to be the case, because the measured background concentrations were fairly consistent and in the expected range. Also, low background RGM concentrations would have caused those values to be higher as well, and this is not the case.

\section{Inefficient Trapping of the RGM in the Annular Denuder}

If the RGM were not trapped in the denuder but passed through to the analyzer, it would be reported as $\mathrm{Hg}^{0}$. However, if the RGM were to pass through the annular denuder, it would most likely be trapped on the particulate filter and be reported instead as particulate-bound $\mathrm{Hg}$. The data for the particulate-bound $\mathrm{Hg}$ concentrations do not suggest this was the case.

\section{Underreported Plume $N O_{\underline{x}}$ Concentrations}

This would result in larger dilution ratios and higher equivalent stack concentrations, but it would affect both the $\mathrm{Hg}^{0}$ and the RGM concentrations. However, if the plume $\mathrm{NO}_{\mathrm{x}}$ concentrations were underreported, it would affect both the $\mathrm{Hg}^{0}$ and RGM concentrations in the same sense, and this is clearly not case.

\section{Problems with the Soda Lime Traps}

Modified soda lime traps were used to scrub acid gases from the sample gas stream before it reached the $\mathrm{Hg}$ analyzer. At the Bowen plant it was observed that $\mathrm{Hg}$ desorbed from these traps when they were exposed to ambient air rather than the scrubbed zero air. There did not appear to be any offgassing of $\mathrm{Hg}$ when sampling ambient air at the Pleasant Prairie plant, but a different type of soda lime trap (supplied by Frontier Geosciences) was used.

\section{CONCLUSIONS}

The following conclusions can be stated based on the Pleasant Prairie Power Plant stack and plume Hg sampling:

- $\mathrm{Hg}$ can be measured by aircraft in plumes with reasonable accuracy and precision. However, great care must be taken to prevent contamination in sampling lines used aboard the aircraft.

- Using a dilution factor based on the plume and stack $\mathrm{NO}_{\mathrm{x}}$, a reasonable $\mathrm{Hg}$ mass balance can be obtained to compare the $\mathrm{Hg}$ in the stack to the $\mathrm{Hg}$ in the plume. 
- There appeared to be a decline in the fraction of RGM at Pleasant Prairie when comparing values in the plume to those in the stack (with a corresponding increase in the proportion of $\mathrm{Hg}^{0}$ ). There was a 38\% reduction of RGM between the in-stack measurement and the first plume sampling point closest to the stack and a 47\% reduction of RGM from the stack to the 5-mile sample point, with no additional reduction evident between the 5-mile and 10-mile locations. This is consistent with earlier measurements by Frontier Geosciences of $\mathrm{Hg}$ reduction reactions in its static plume dilution chamber, which indicated rapid reduction reactions after mixing of flue gas emissions with ambient air conditions representing the region just outside the stack exit.

\section{ACKNOWLEDGMENTS}

The authors would like to acknowledge the following:

- The DOE National Energy Technology Laboratory Project Manager Bill Aljoe.

- The Wisconsin Department of Administration, which with EPRI and DOE helped fund the project.

- We Energies, which graciously allowed us to use its facility at Pleasant Prairie for the test program.

Also, the authors would like to thank the other participants in the project. They include Dave Delene from the University of North Dakota Center for Aerospace Sciences; Eric Prestbo from Frontier Geosciences; Ray Valente from TVA; and the pilots and crew from Twin Otter.

\section{REFERENCES}

1. Presbo, E.M.; Calhoun, J.A.; Brunette, R.C.; Paladini, M. Hg Speciation in a Simulated Coal Combustion Plume. In Proceedings of Air Quality: Mercury, Trace Elements, and Particulate Matter Conference; McLean, VA, Dec 1-4, 1998.

2. Danilchik, P; Imhoff, R. Liang, L.; Valente, R.; Dismukes, E.; Brown, C.; Spurling, D.; Huang, Z.; Prestbo, E. A Comparison of the Fate of Mercury in Flues and Plumes of CoalFired Boilers. Presented at the Mercury as a Global Pollutant Conference, Whistler, BC, July 10-14, 1994.

3. Imhoff, R.E. Preliminary Report on Measurements of Gas- and Particle-Phase Mercury in the Plumes of Coal-Fired Boilers, Atmospheric Sciences Department, Environmental Research Center, Tennessee Valley Authority, March 15, 1995.

4. Laudal, D.L; Prestbo, E. Investigation of the Fate of Mercury in a Coal Combustion Plume Using a Static Plume Dilution Chamber; Final Report for U.S. Department of Energy 
Contract No. DE-FC-26-95FT40321; Energy \& Environmental Research Center: Grand Forks, ND, Oct 2001.

5. Edgerton, E.; Hartsell, B. Jansen, J. Field Observations of Mercury Partitioning in Power Plant Plumes. In Proceedings of the International Conference on Air Quality III: Mercury, Trace Elements, and Particulate Matter, Arlington, VA, Sept 2002.

\section{KEYWORDS}

mercury, utilities, plume 